\title{
Assessment of the Dynamics of Microbial Community Associated with Tetraselmis suecica Culture under Different LED Lights Using Next-Generation Sequencing
}

\author{
Su-Jeong Yang ${ }^{1 \dagger}$, Hyun-Woo Kim ${ }^{1 \dagger}$, Seok-Gwan $\mathrm{Choi}^{2}$, Sangdeok Chung ${ }^{2}$, Seok Jin $\mathrm{Oh}^{3}$, Shweta Borkar ${ }^{4}$, and \\ Hak Jun Kim $^{4 *}$ \\ ${ }^{1}$ Interdisciplinary Program of Biomedical, Mechanical and Electrical Engineering, Pukyong National University, Busan 48513, Republic of Korea \\ ${ }^{2}$ National Institute of Fisheries Science (NIFS), Busan 46083, Republic of Korea \\ ${ }^{3}$ Department of Oceanography, Pukyong National University, Busan 48513, Republic of Korea \\ ${ }^{4}$ Department of Chemistry, Pukyong National University, Busan 48513, Republic of Korea
}

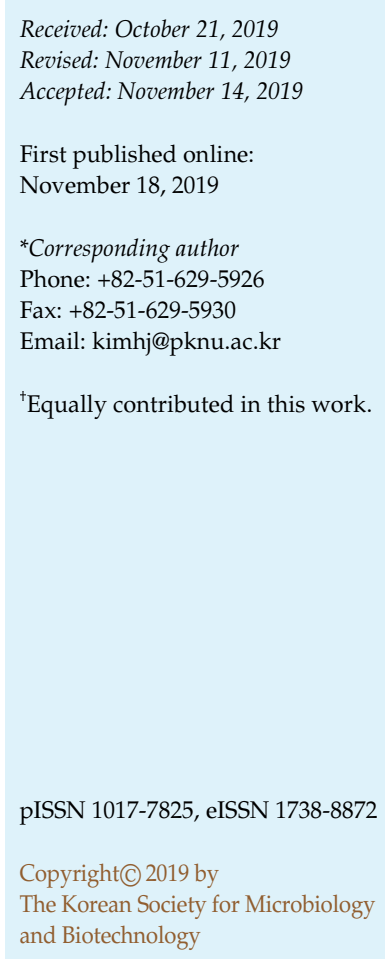

Tetraselmis is a green algal genus, some of whose species are important in aquaculture as well as biotechnology. In algal culture, fluorescent lamps, traditional light source for culturing algae, are now being replaced by a cost-effective light-emitting diodes (LEDs). In this study, we investigated the effect of LED light of different wavelengths (white, red, yellow, and blue) on the growth of Tetraselmis suecica and its associated microbial community structures using the next-generation sequencing (NGS). The fastest growth rate of T. suecica was shown in the red light, whereas the slowest was in yellow. The highest OTUs (3426) were identified on day 0 , whereas the lowest ones (308) were found on day 15 under red light. The top 100 OTUs associated with day 0 and day 5 cultures of T. suecica under the red and yellow LED were compared. Only 26 OTUs were commonly identified among four samples. The highest numbers of unique OTUs were identified at day 0 , indicating the high degree of initial microbial diversity of the T. suecica inoculum. The red light-unique OTUs occupied 34.98\%, whereas the yellow-specific OTUs accounted for only $2.2 \%$. This result suggested a higher degree of interaction in T. suecica culture under the red light, where stronger photosynthesis occurs. Apparently, the microbial community associated with T. suecica related to the oxygen produced by algal photosynthesis. This result may expand our knowledge about the algaebacteria consortia, which would be useful for various biotechnological applications including wastewater treatment, bioremediation, and sustainable aquaculture.

Keywords: Next-generation sequencing, metagenomics, LED, microalgae, microbial community

\section{Introduction}

Tetraselmis is a green algal genus, some of whose species are widely aquacultured as good food sources for bivalves, penaeid shrimp larvae, and rotifers [1]. These marine microalgae are known to have a large spectrum of antimicrobial activity [2,3] along with high potential as a probiotic for fish [4]. Tetraselmis has also been proposed as a source of vitamins or fatty acids for humans and animals
[5-7]. In addition, mass culturing of Tetraselmis is essential for biofuel production and has been carried out in various studies $[8,9]$. As one of the cost-effective algal culture system, the traditional fluorescent lamps are now being replaced by a light-emitting diodes (LEDs) for its longer lifespan and higher electrical efficiency

Since microalgae are photosynthetic organisms, light is the most important factor in culturing them. Many studies on algae were performed to understand the wavelength 
dependence of the photosynthesis process, while the effect of the exposure to different light spectra has been much less investigated [10]. Microalgae require optimal light conditions to achieve maximum photosynthetic rate economically [11]. Located at the bottom of the aquatic food chain, microalgae are autotrophic organisms that produce organic matter through photosynthesis. They form colonies or are surrounded by a microbiome of mucous substances called the 'phycosphere,' where many bacteria are attached and symbiotic. Strong interactions between microalgae and bacteria occur in the phycosphere and can have either a positive or negative effect on each other. Bacteria provide microalgae with $\mathrm{CO}_{2}$, inorganic nutrients, and vitamin sources, but obtain the oxygen and extracellular substances generated by microalgae. Microalgae and bacteria exist together in almost all aquatic environments and play key roles in nutrient cycling and energy flow $[12,13]$

Microbial communities are usually examined by morphological identification. However, since the bacterial communities are difficult to observe directly, they are first separated by isolation and then analyzed using methods such as clone libraries or RFLP [14, 15], which requires a lot of time and effort. Next-generation sequencing (NGS) is a technique used to quickly analyze microbiota in detail without isolating the microorganism separately [16, 17]. There are two ways; the first is a nucleotide sequence analysis targeting $16 \mathrm{~S}$ rRNA and the second is a shotgun method. We chose the former, using DNA barcodes. The $16 \mathrm{~S}$ rRNA has a conserved region common to all species and a hypervariable region which is used as a DNA barcode that can classify specific species. With NGS, metagenomic analysis makes it possible to identify all species in a sample, even those that are present in low abundance. The Illumina Miseq platform in particular generates a large number of high-quality sequence reads that enable detection of the microbial taxa across a high number of taxonomic profiles from samples [18].

It was confirmed that the growth of microalgae varied depending on different wavelengths [11, 19]. As a result, interacting microorganisms are affected by wavelength or the rate of photosynthesis of algae. However, little research has been done on the effect of light wavelengths on the algae-microbiome community structure. In this study, we investigated the effect of LED light of different wavelengths (white, red, yellow, blue) on the growth rate of T. suecica and its associated microbial communities using nextgeneration sequencing (NGS) technology.

\section{Materials and Methods}

\section{Culture}

The experimental species $T$. suecica was received from the Library of Marine Samples, KIOST, Korea. For the culture, f/2 medium was used, which was filtered $(0.22 \mu \mathrm{m}$ pore size, Millipore GSWP) with selenium to a final concentration of $0.001 \mu \mathrm{M}$. The medium was maintained at $20^{\circ} \mathrm{C}, 30 \mathrm{psu}$, with light intensity of about $100 \mu \mathrm{mol} / \mathrm{m}^{2} / \mathrm{s}$ (12L: 12D; cool-white fluorescent lamp). The experimental instruments were UV-treated for $20 \mathrm{~min}$ or more, and all experiments were performed on a clean bench.

As a light source, a fluorescent lamp with multiple wavelengths, a red light $(650 \mathrm{~nm})$, a yellow light $(590 \mathrm{~nm})$, and a blue light $(450 \mathrm{~nm})$ were used. The microalgae were grown to a late stage of the logarithmic growth phase under a cool-white fluorescent lamp (12L: $12 \mathrm{D})$ at $20^{\circ} \mathrm{C}, 30 \mathrm{psu}$ and then inoculated to a final density of cells with about $1.0 \times 10^{2}$ in $\mathrm{f} / 2$ medium 3L [20]. For each condition, two bottles were used.

\section{Genomic DNA Extraction}

From the mass cultured samples, $15 \mathrm{ml}$ was filtered through a $0.45 \mu \mathrm{M}$ GN-6 membrane filter (Pall Corporation, USA) every 5 days until the $25^{\text {th }}$ day. Next, the filters were homogenized with a TissueLyser II (QIAGEN, Germany) and incubated in a heat block at $60^{\circ} \mathrm{C}$ for $2 \mathrm{~h}$. Then, genomic DNA was extracted using a DNeasy Plant Mini Kit (QIAGEN) following the manufacturer's instructions and stored at $-70^{\circ} \mathrm{C}$ until used as a template for qPCR and library preparation.

\section{Quantitative PCR Analysis of T. suecica}

Genomic DNA was quantified by quantitative real-time PCR (qPCR) with phytoplankton primers P23MISQF1 and P23MISQR1 targeting plastid $23 \mathrm{~S}$ ribosomal DNA and $341 \mathrm{~F}$ and 785R targeting $16 \mathrm{~S}$ ribosomal DNA to measure the relative number of T. suecica and microbial community, respectively (Table 1). The PCR mixture $(20 \mu \mathrm{l})$ contained $4 \mu \mathrm{l}$ ultrapure water, $1 \mu \mathrm{l}$ forward and reverse primer $(10 \mu \mathrm{M})), 10 \mu \mathrm{l} 2 \mathrm{X}$ SYBR Green Premix Ex Taq II (Takara Bio Inc., Japan) and $4 \mu$ l genomic DNA as a template. Real-time PCR was carried out under the following conditions: initial denaturation step at $94^{\circ} \mathrm{C}$ for $3 \mathrm{~min}$, followed by 35 cycles of denaturation at $94^{\circ} \mathrm{C}$ for $30 \mathrm{sec}$, annealing at $55^{\circ} \mathrm{C}$ for $30 \mathrm{sec}$, and extension at $72^{\circ} \mathrm{C}$ for $30 \mathrm{sec}$. The process was completed with a final extension at $72^{\circ} \mathrm{C}$ for $5 \mathrm{~min}$. A standard curve was constructed using plasmid containing each primer set with a range of $0.01 \mathrm{pg}$ to $0.01 \mathrm{ng}[21,22]$. The reaction was performed using a DNA Engine Chromo 4 Real-Time PCR Detection System (Bio-Rad, USA).

\section{NGS Library Preparation and Sequencing}

In order to analyze the microbial community structures associated with the growth of T. suecica, cultures at day 5 and day 15 under the red and yellow LED lights were harvested and 
Table 1. Primers used in this study.

\begin{tabular}{llc}
\hline \multicolumn{1}{c}{ Name } & \multicolumn{1}{c}{ Sequence (5' to ${ }^{\prime}$ ) } & Target region \\
\hline $341 \mathrm{~F}$ & CCTACGGGNGGCWGCAG & $16 \mathrm{~S}$ \\
$785 \mathrm{R}$ & GACTACHVGGGTATCTAATCC & $16 \mathrm{~S}$ \\
P23MISQF1 & GGACARWAAGACCCTATGMAG & $23 S$ \\
P23MISQR1 & AGATYAGCCTGTTATCCCT & 235 \\
Forward adaptor & TCGTCGGCAGCGTCAGATGTGTATAAGAGACAG & \\
Reverse adaptor & GTCTCGTGGGCTCGGAGATGTGTATAAGAGACAG & \\
\hline
\end{tabular}

samples at day 0 were used as a control. The first PCR was conducted using $341 \mathrm{~F}$ and $785 \mathrm{R}$ with overhanging adaptors for MiSeq Sequencing (Table 1). The PCR mixture $(20 \mu \mathrm{l})$ contained $1 \mu \mathrm{l}$ primer $(10 \mu \mathrm{M}$, forward and reverse), $0.1 \mu \mathrm{l}$ Ex Taq DNA polymerase (TaKaRa), $2 \mu \mathrm{l}$ Ex 10X Buffer, $2 \mu \mathrm{l}$ dNTPs $(0.5 \mu \mathrm{M}$, TaKaRa), ultrapure water and a template. The amounts of ultrapure water and template were adjusted to have the same DNA concentrations for the library construction as well as the samples. The PCR was performed under the following conditions: initial denaturation step at $94^{\circ} \mathrm{C}$ for $3 \mathrm{~min}$, followed by 10 cycles of denaturation at $94^{\circ} \mathrm{C}$ for $30 \mathrm{sec}$, annealing at $55^{\circ} \mathrm{C}$ for $30 \mathrm{sec}$, and extension at $72^{\circ} \mathrm{C}$ for $30 \mathrm{sec}$. The process was completed with a final extension at $72^{\circ} \mathrm{C}$ for $3 \mathrm{~min}$. The first PCR products were separated by $1.5 \%$ agarose gel electrophoresis and stained with loading star dye (Dynebio, Korea). Amplicons with the expected size (511 bp) were cut from the gel and purified using an AccuPrep Gel Purification Kit (Bioneer, Korea) for the second PCR, which was performed using Illumina Nextera XT indexing primers (Table 1). The PCR mixture $(20 \mu \mathrm{l})$ contained $9.3 \mu \mathrm{l}$ of ultrapure water, $1 \mu \mathrm{l}$ primer $(10 \mu \mathrm{M}$, forward and reverse), $0.5 \mu \mathrm{l}$ Phusion High Fidelity DNA polymerase (NEB, UK), $4 \mu \mathrm{l} 5 \mathrm{X}$ Phusion Buffer, $0.5 \mu \mathrm{l}$ dNTPs $(10 \mu \mathrm{M}$, TaKaRa) and $4 \mu \mathrm{l}$ purified first PCR products as a template and the PCR was carried out under the following conditions: initial denaturation step at $94^{\circ} \mathrm{C}$ for $3 \mathrm{~min}$, followed by 15 cycles of denaturation at $94^{\circ} \mathrm{C}$ for $30 \mathrm{sec}$, annealing at $55^{\circ} \mathrm{C}$ for $30 \mathrm{sec}$, and extension at $72^{\circ} \mathrm{C}$ for $30 \mathrm{sec}$. The process was completed with a final extension at $72^{\circ} \mathrm{C}$ for $3 \mathrm{~min}$. Then, gel purification was performed as described above. The quality and quantity of the libraries were measured using a 2100 Bioanalyzer (Agilent Technologies, USA) and sequencing was performed at $300 \mathrm{bp}$ paired-end reads with a MiSeq sequencer (Illumina, USA).

\section{Bioinformatics of NGS Data}

Among the raw data, sequences with under QV 20 and read length less than 100 nucleotides were trimmed using the CLC Genomic Workbench v.8.0 (CLC Bio, USA). End-paired amplicons were constructed with over $6 \mathrm{bp}$ overlapping sequences and omitting any mismatches option, size selection (400 500 bp), and primer trimming with the pdiffs $=1$ option were performed using Mothur software v.1.35.0 [23]. Operational taxonomic units with $99.6 \%$ similarity cutoff were clustered and chimeras were removed using UCHIME software v.8.1 (http://drive5.com/ uchime). OTUs with less than $0.001 \%$ of total reads were removed. The sequences of OTUs were compared against known species from the NCBI-NT database using BLAST (BLASTN, version 2.2.30+). OTU sequences with more than $97 \%$ identity to the database were assigned to the top-hit species names while genus names were assigned for OTUs with 90 96\% identity. OTUs with less than $90 \%$ identity to the database were described as "unclassified." The Venn diagram was generated with Draw Venn Diagram (http:/ / bioinformatics.psb.ugent.be /webtools/Venn/).

\section{Results}

\section{Quantitative Analysis of Microbial Community}

According to qPCR result with P23MISQF1 and P23MISQR1 primer set, the fastest growth rate of T. suecica was identified under the red LED light followed by white, blue and yellow (Fig. 1A). The rate was steadily increased in all wavelengths during the study period, but not in the red wavelength on day 25 . The $341 \mathrm{~F}$ and $785 \mathrm{R}$ primer is a universal primer set that amplifies the 16S rRNA region of microorganisms. The number of microorganisms increased steeply after one day of cultivation, reaching a peak and showing fast growth rate compared with T. suecica (Fig. 1B). Thereafter, microbial copy numbers did not show any significant changes, indicating the limit of nutrition in the culture. It was noteworthy that the lowest copy numbers of total microorganism were also shown in the culture under the yellow light throughout the culture time. This may have come from the low amount of organic carbon source by $T$. suecica under the light. As shown in Fig. $1 C$, the ratio of T. suecica to total bacteria was low until day 10 of inoculation, but this ratio increased significantly thereafter. (Fig. 1C). This result indicated the exponential growth of $T$. suecica approximately 10 days after inoculation.

\section{Community Structures Generated by Next-Generation Sequencing}

Microbial community structures associated with the growth rates of $T$. suecica were analyzed by a next-generation 

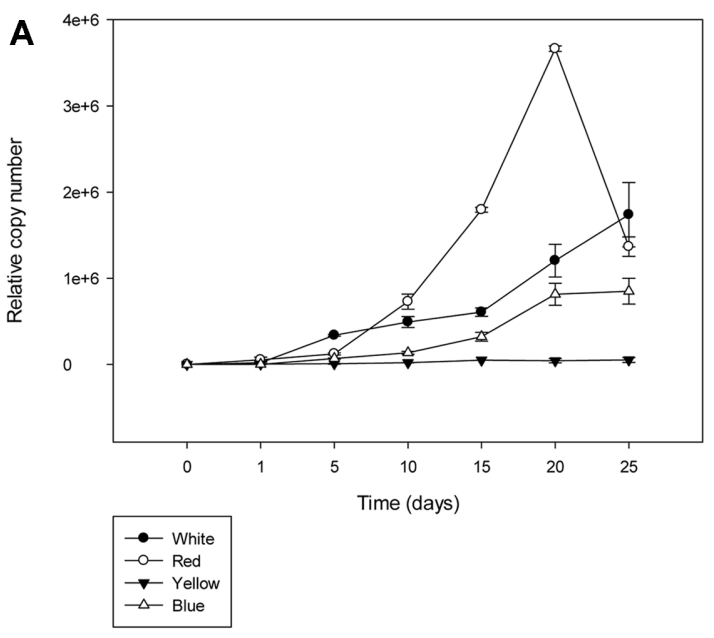

B
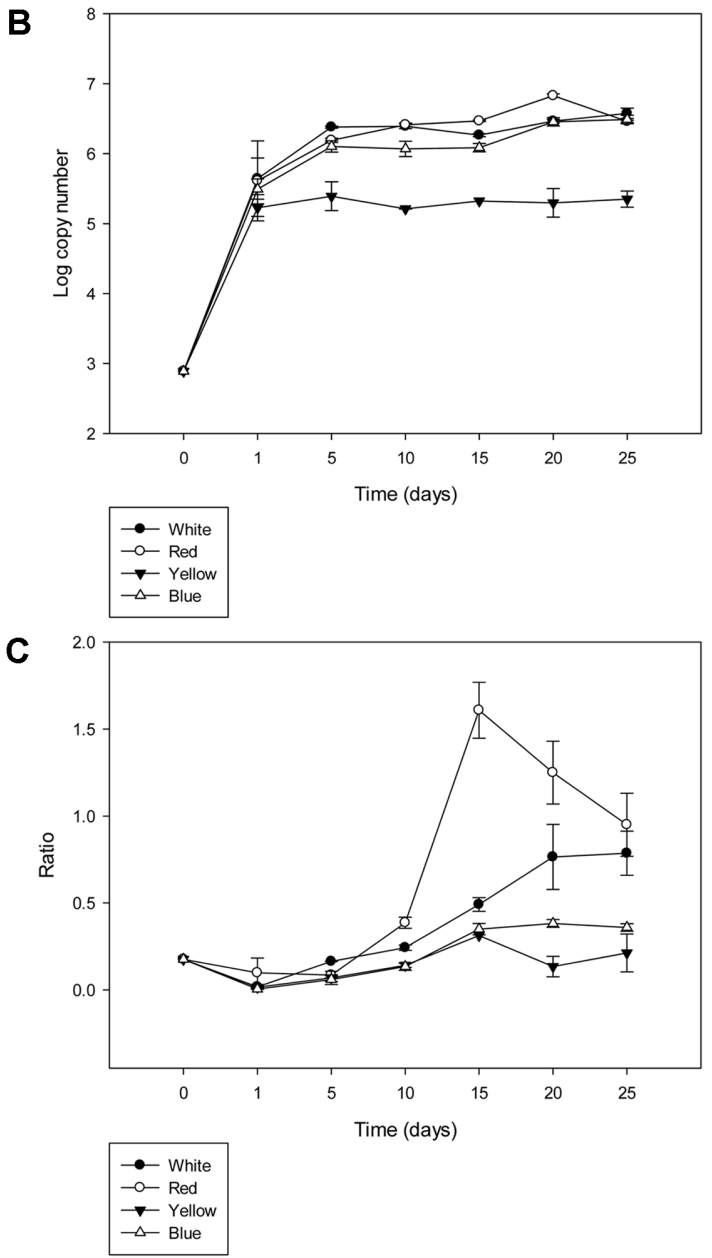

Fig. 1. Quantitative PCR result of Tetraselmis suecica and its associated microorganisms grown under the four different wavelength LED lights.

(A) The relative copy numbers of T. suecica measured by the plastid $23 \mathrm{~S}$ rDNA. (B) The relative copy numbers of microorganisms by the numbers of $16 \mathrm{~S}$ rRNA. (C) The ratio of T. suecica to total bacteria in different cultivation times. sequencing (NGS) technique using $341 \mathrm{~F}$ and $785 \mathrm{R}$ primer. The cultures on days 5 and 15 under the red light were chosen as 'fast-growing' microbial communities, whereas those under the yellow light were named 'slow-growing' communities. The day 0 community was analyzed as the control. All OTUs were assigned to species if the similarity was $97 \%$ or more, to genus if similarity was $90-96 \%$, and to unclassified if less than $90 \%$. Most OTUs showed more than $97 \%$ sequence identity to the database. The obtained OTUs numbers ranged from 308 to 3426 . The highest OTU numbers were identified on day 0 (3426), whereas the lowest ones were found on day 15 under the red light (15R). For our convenience, OTUs with lower than $0.001 \%$ of total reads were eliminated from further analysis, which occupied approximately $2-4 \%$ of total read numbers. Obtained OTUs were classified into 1 phytoplankton phylum including Chlorophyceae and 8 bacterial classes including Actinobacteridae, Alphaproteobacteria, Cytophagia, Flavobacteria, Gammaproteobacteria, Phycisphaerae, Planctomycetacia, and Sphingobacteria (Table 2). Smaller class numbers were identified in the red lights (17 on day 15 and 21 on day 5), whereas its higher numbers were found in the yellow light (29 on both day 15 and day 5). Day 0 showed the highest microbial class numbers. Collectively, lower microbial taxa were identified in the 'fast-growing' T. suecica cultures, suggesting strong photosynthesis has an adverse effect in several microbial classes such as Planctomycetia, which was identified only in the yellow light (Table 2).

Microbial community structures with different culture times and lights were compared (Table 3 and Fig. 2). T. suecica dominated in all the examined cultures except for day 5 under yellow light (5Y). On day 0, T. suecica occupied about $34 \%$ followed by $M$. roseacus (30\%), Rhabdobacter $\mathrm{sp}$ $(8 \%)$, and Halomonas sp. (7\%). In 5R, T. suecica accounted for about half of the community, 21\% Halomonas sp., 17\% Alteromonas australica, $6 \% \mathrm{M}$. roseacus. In day 5 under the yellow light (day 5Y), M. roseacus occupied 38\% followed by $11 \%$ of Pseudomonas sp., and 6\% of Rhabdobacter sp. On day $15, M$. roseacus accounted for $37 \%$ and $33 \%$ in the red and yellow lights, respectively. $M$. roseacus was dominant compared to other bacteria (Fig. 2A). Except for T. suecica, the community structure of $5 \mathrm{R}$ appeared different than $5 \mathrm{Y}$ compared to the day of inoculation. On day 15, there were only a small number of bacteria that were present on day 5 , and $M$. roseacus was most dominant. (Fig. 2B).

Microbial community structures associated with $T$. seucica cultures under the LED lights with two different wavelengths were compared (Fig. 3). First, we compared the top 
Table 2. Summary of OTUs generated by $16 \mathrm{~S}$ universal primers at day 0,5 , and 15 samples under the red and yellow lights.

\begin{tabular}{|c|c|c|c|c|c|c|c|c|c|c|}
\hline \multirow[b]{2}{*}{ Class } & \multicolumn{2}{|c|}{ Day 0} & \multicolumn{2}{|c|}{ Day 5 - Red } & \multicolumn{2}{|c|}{ Day 5 - Yellow } & \multicolumn{2}{|c|}{ Day 15 - Red } & \multicolumn{2}{|c|}{ Day 15 - Yellow } \\
\hline & OTUs & $\begin{array}{l}\text { Proportion } \\
(\%)\end{array}$ & OTUs & $\begin{array}{c}\text { Proportion } \\
(\%)\end{array}$ & OTUs & $\begin{array}{c}\text { Proportion } \\
(\%)\end{array}$ & OTUs & $\begin{array}{c}\text { Proportion } \\
(\%)\end{array}$ & OTUs & $\begin{array}{c}\text { Proportion } \\
(\%)\end{array}$ \\
\hline Actinobacteridae & 1 & 1.72 & & & & & & & & \\
\hline Alphaproteobacteria & 13 & 36.32 & 7 & 7.15 & 12 & 44.21 & 7 & 38.78 & 14 & 38.20 \\
\hline Chlorophyceae & 1 & 34.23 & 1 & 50.08 & 1 & 23.21 & 1 & 55.38 & 1 & 54.33 \\
\hline Cytophagia & 2 & 8.15 & & & 1 & 6.21 & 1 & 0.89 & 1 & 1.58 \\
\hline Flavobacteriia & 1 & 0.12 & 1 & 0.26 & & & 1 & 0.22 & & \\
\hline Gammaproteobacteria & 18 & 18.09 & 10 & 41.05 & 11 & 22.35 & 5 & 2.77 & 7 & 3.05 \\
\hline Phycisphaerae & 1 & 1.14 & 1 & 1.25 & 1 & 2.57 & 1 & 1.57 & 1 & 1.46 \\
\hline Planctomycetia & & & & & 1 & 0.99 & & & 2 & 0.63 \\
\hline Sphinogobacteriia & 1 & 0.23 & 1 & 0.22 & 1 & 0.33 & 1 & 0.39 & 2 & 0.50 \\
\hline Unclassified & & & & & 1 & 0.14 & & & 1 & 0.25 \\
\hline Total & 38 & 100.00 & 21 & 100.00 & 29 & 100.00 & 17 & 100.00 & 29 & 100.00 \\
\hline
\end{tabular}

100 OTUs among day 0, day 5 under the yellow (5Y) and red (5R) using the Venn-diagram (Fig. 3A). Only 26 OTUs were commonly identified among day $0,5 R$, and $5 \mathrm{Y}$. The highest numbers of unique OTUs were identified at day 0 indicating the high degree of initial microbial diversity of the T. suecica inoculum. The highest proportion of unique OTUs were identified in the red light (34.98\%), whereas the yellow-specific OTUs occupied only 2.2\% (Table 4-1) This result suggested that a higher degree of interaction in T. suecica culture under the red light, in which its strong photosynthesis occurs. By contrast, the highest proportion of shared OTUs with those in day 0 were identified in $5 \mathrm{Y}$ (19\%) compared with those in 5R (Table 4-1 and Fig. 3A).

On day 15 , compared with the remaining OTUs in the red and yellow wavelengths, the numbers of shared OTU were 37 , but the shared proportions were $97.31 \%$ and $91.2 \%$, respectively, in which $M$. roseacus was the most abundant bacteria (Table 4-2). Duplicated experiments were conducted to determine the microbiota associated with the growth of photosynthetic T. seucica (Figs. 3C and 3D). On day 15, the microbial communities under the red light exhibited a high degree of similarity sharing 53 OTUs with $98.56 \%$ and $97.93 \%$ identity in their proportions. By contrast, microbial communities in duplicated experiments under the yellow light showed higher degree of dissimilarity, sharing only 13 OTUs with $62.73 \%$ and $3.89 \%$ identity (Fig. 3D). This result suggested that the microbial community associated with $T$. suecica is strongly related to photosynthesis.

The reproducibility of the microbial community associated with $T$. suecica was tested by the replication of the experiment (Table 4-3,4). We found that 53 OTUs shared between two independent cultures under the red light on day 5 occupied 99\% and 98\%, respectively (Fig. 3C). Although the numbers of unique OTUs in each culture under the red light were 43 (5R-1) and 41 (5R-2), their proportions were negligible, indicating that the microbial community associated with the growth of T. suecica was not a result of random combination of bacterial components. For the slow growth T. suecica under the yellow light, which exhibited the low photosynthetic efficiency, only 13 OTUs were shared and their proportions were 63\% and $96 \%$, respectively, depending on the growth of $T$. suecica (Table 4-3 and Fig. 3C). Collectively, on day 5, the efficiency of photosynthesis of T. suecica may have been the critical factor in determining microbial community.

\section{Discussion}

In this study, we investigated the effect of the LED light with different wavelengths (white, red, yellow, blue) on the growth rate of $T$. suecica and its associated microbial communities using next-generation sequencing (NGS) technology. Analysis of microbial community structure using NGS techniques revealed significantly higher diversity than the traditionall methods including the clone libraries or DGGE community profiling [24]. The primer set used in the present study, 341F and 785R, has been proven to show the wide range of microbial taxa coverage with little non-specific amplification [25, 26]. The results of artificial conditions in the laboratory are essential to understanding the growth characteristics in outdoor cultures [27]. The culture was non-axenic, which is associated with bacteria present in the natural environment and cultured with algae [16]. Besides, the non-axenic microalgae cultures 


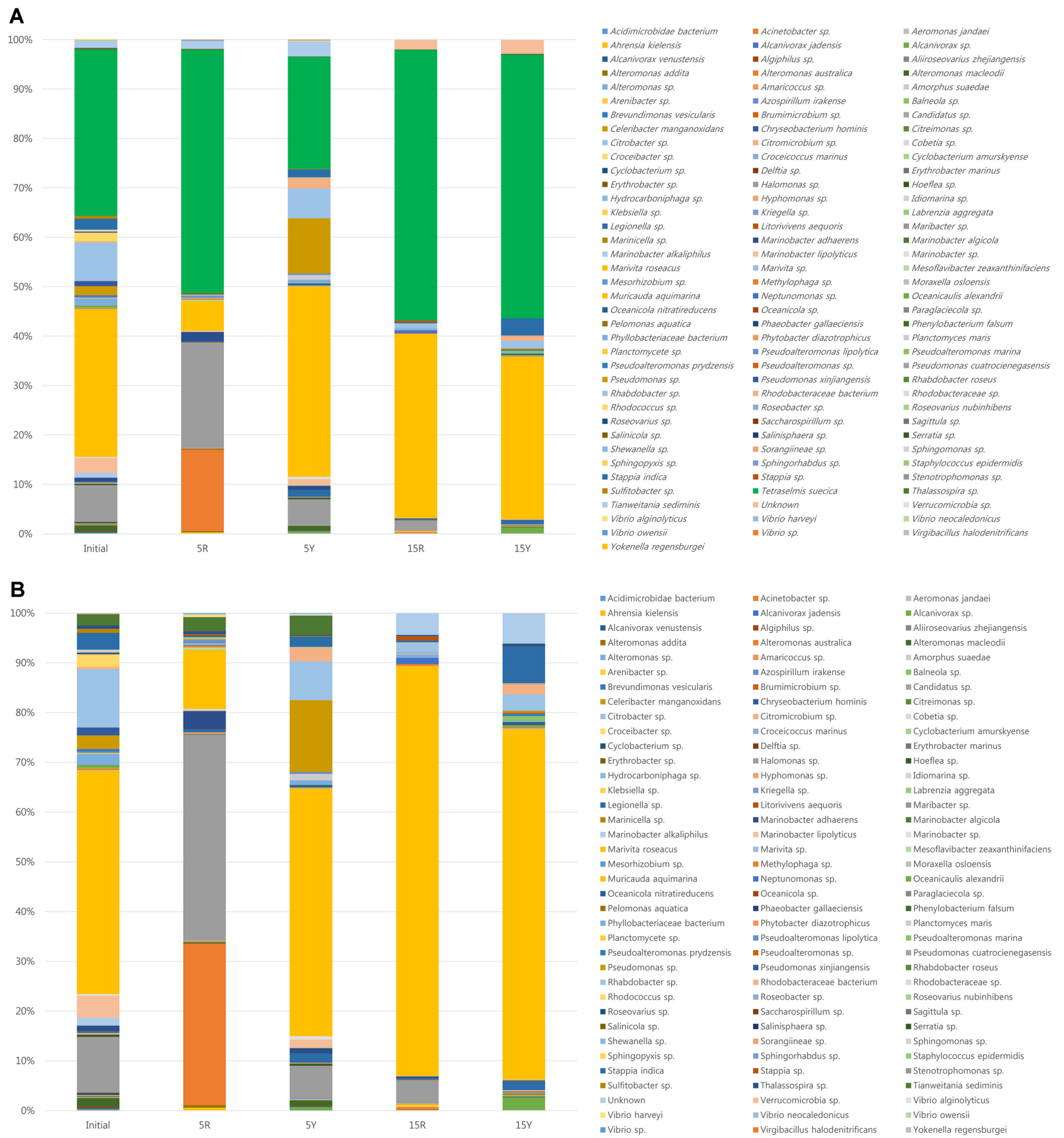

Fig. 2. Microbial community structure at species level on day 0 , day 5 of the red and yellow wavelengths with T. suecica included (A) and excluded (B).

Each bar shows the proportion of microbial species according to $97 \%$ sequence similarity.

are applied in the green-water technique, and it is important to recognize the microbiota associated with the microalgae cultures [28].
A light regime generally produces the most intense photosynthesis at wavelength from 575 to $720 \mathrm{~nm}$, and is most effective in the red $(650 \sim 680 \mathrm{~nm})$ and blue $(400 \sim 500 \mathrm{~nm})$. 
A

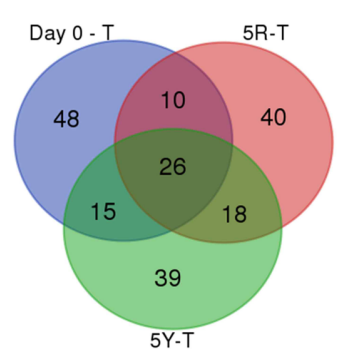

C

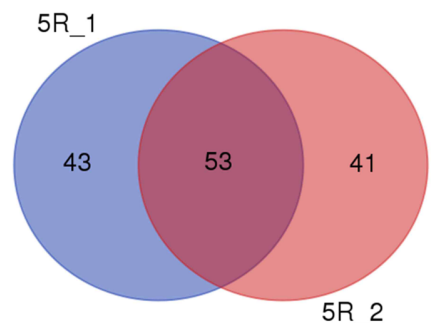

\section{B}

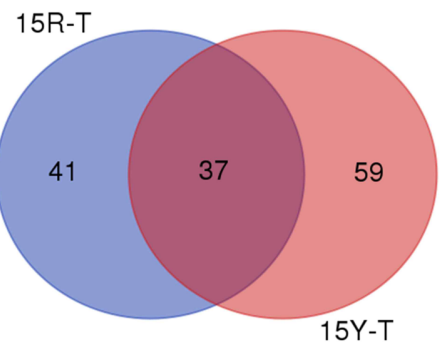

D

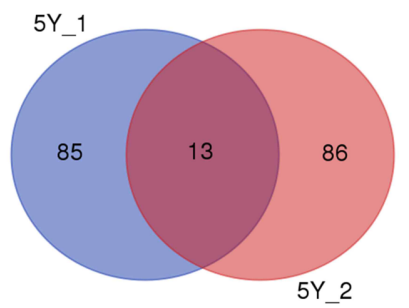

Fig. 3. Three-way Venn diagram illustrating the number of shared and specific OTUs among the day of inoculation and day 5 (A), between the red and yellow wavelengths on day 15 (B), between same wavelengths of red light $(\mathrm{C})$, and yellow light (D).

According to the previous study, the growth rate of $T$. suecica under different types of wavelengths was reported to be fast in order of white, red and blue [29], but in this study, red had the fastest growth rate followed by white, blue, and yellow. This result may be due to the difference in the white light source. The spectrums of commercially available white light lamps are different and the white fluorescent lamp in this study may not be effective as one in another study. Further study should be conducted to compare white lamps with different spectrums. The samples cultured until the $25^{\text {th }}$ day seemed to reach the stationary phase and the red wavelength with the fastest growth seemed to be the death phase from the $15^{\text {th }}$ day presumably due to the nutritional limit in the culture (Fig. 1).

After a day of inoculation, the ratio of $T$. suecica to bacteria is low because bacterial growth is much faster than eukaryotic microalgae consuming the organic nutrients in the subculture, but soon its growth rate is decreased by the limited amount of the organic nutrient before the growth of T. suecica, which further provides it by photosynthesis (Fig. 3). In fact, we have found that T. suecica was the least abundant among the samples at the slowest growing yellow wavelength (Fig. 4). This appears to be due to the relatively low photosynthesis of algae at the yellow wavelength providing the low amounts of organic matter for bacterial use.

While the proportion of other bacteria decreased over time, only $M$. roseacus increased in the culture of $T$. suecica (Fig. 4). Marivita is a heterotrophic and strictly aerobic bacterium, which is closely associated with the algae [30]. Therefore, given the high number of $T$ suecica, the higher amount of the produced oxygen may have facilitated the growth of this bacterium. $M$. roseacus is a novel species that was first reported to be isolated from the surface of a coccolithophore. It appears to be beneficial to the growth of algae, which may exhibit specific dependence between bacteria and algae even though the genus Marivita may be a product induced by artificial laboratory culture experiments [30]. Probably because of its special metabolic pathway to algae, it may occupy half of the community composition on day 15 and have growth priority compared to other bacteria. So, $M$. roseacus seemed to be predominant despite the different wavelengths (Fig. 2). Alternatively, M. roseacus is known to produce bacteriochlorophyll $a$, which can survive by photosynthesis in conditions with limited organic carbon sources [31]. Certain bacteria have been reported to exert an effect on microalgae, indicating that the combination of microalgae and bacteria may be decisive for co-culture [12].

It is conceivable that bacteria will interact with microalgae with nutrients during the culture. Here, we demonstrated that fast-growing bacteria consumed organic nutrients quickly in the subculture, and metabolites generated by bacterial communities affected the growth of the microalgae as well. However, it is surprising to find out that the remaining bacterial community on day 15 shared about half of its OTUs and its proportion of contigs was more than 90\% (Table 4-2 and Fig. 3B). The community structures between the two samples were also highly similar to each other. A similar result was also shown in the study by Han, in which bacterial density remained at a similar level by consuming the original organic substance and resulted in a similar microalgal density [12]. Therefore, the fast-growing bacteria determined the initial microbial community with little effect by the low-numbered microalgae. Although the growth of both microalgae and bacteria is affected by their complex interactions, the initial community composition appears to be determined by the random composition of the inoculated bacteria in the subcultured samples. Thereafter, the determined bacterial community can be harmful or beneficial to the growth of a microalgae affecting its growth. The experiment was duplicated per each condition, and the community structures of two 


\begin{tabular}{|c|c|c|c|c|c|c|c|c|c|c|c|c|c|c|c|}
\hline \multicolumn{4}{|c|}{ Day 0} & \multicolumn{3}{|c|}{ Day 5 - Red } & \multicolumn{3}{|c|}{ Day 5 - Yellow } & \multicolumn{3}{|c|}{ Day 15 - Red } & \multicolumn{3}{|c|}{ Day 15 - Yellow } \\
\hline No & Species & $\begin{array}{l}\text { GenBank } \\
\text { number }\end{array}$ & $\begin{array}{c}\text { Propor- } \\
\text { tion } \\
(\%)\end{array}$ & Species & $\begin{array}{l}\text { GenBank } \\
\text { number }\end{array}$ & $\begin{array}{c}\text { Propor- } \\
\text { tion } \\
(\%) \\
\end{array}$ & Species & $\begin{array}{l}\text { GenBank } \\
\text { number }\end{array}$ & $\begin{array}{c}\text { Propor- } \\
\text { tion } \\
(\%)\end{array}$ & Species & $\begin{array}{l}\text { GenBank } \\
\text { number }\end{array}$ & $\begin{array}{c}\text { Propor- } \\
\text { tion } \\
(\%)\end{array}$ & Species & $\begin{array}{l}\text { GenBank } \\
\text { number }\end{array}$ & $\begin{array}{c}\text { Propor- } \\
\text { tion } \\
(\%)\end{array}$ \\
\hline 1 & $\begin{array}{l}\text { Tetraselmis } \\
\text { suecica }\end{array}$ & KU167097 & 34.00 & $\begin{array}{l}\text { Tetraselmis } \\
\text { suecica }\end{array}$ & KU167097 & 50.08 & $\begin{array}{l}\text { Marivita } \\
\text { roseacus }\end{array}$ & NR_132662 & $\begin{array}{rl}38.34 & 7 \\
s & \end{array}$ & $\begin{array}{l}\text { Tetraselmis } \\
\text { suecica }\end{array}$ & KU167097 & 55.38 & $\begin{array}{l}\text { Tetraselmis } \\
\text { suecica }\end{array}$ & KU167097 & 54.33 \\
\hline 2 & Marivita roseacus & NR_132662 & 30.15 & Halomonas sp. & KY474018 & 20.78 & Tetraselmis suecica & KU167097 & 23.211 & Marivita roseacus & NR_132662 & 37.261 & Marivita roseacus & NR_132662 & 31.99 \\
\hline 3 & Rhabdobacter sp. & NR_147750 & 7.88 & Alteromonas sp. & КР099958 & 16.72 & Pseudomonas sp. & KY020318 & $11.38 \mathrm{~F}$ & Halomonas sp. & KY474018 & 2.09 & Stappia indica & KY616246 & 2.84 \\
\hline 4 & Halomonas sp. & LT934170 & 7.55 & Marivita roseacus & NR_132662 & 6.01 & Rhabdobacter sp. & NR_147750 & $6.21 \mathrm{~L}$ & Unclassified & & $1.57 \quad 1$ & Rhabdobacter sp. & NR_147750 & 1.58 \\
\hline 5 & $\begin{array}{l}\text { Marinobacter } \\
\text { lipolyticus }\end{array}$ & KX818042 & 2.96 & $\begin{array}{l}\text { Marinobacter } \\
\text { adhaerens }\end{array}$ & KY601871 & 1.88 & Halomonas sp. & KY474018 & $5.10 I$ & Rhabdobacter $s p$. & NR_147750 & 0.89 & Unclassified & & 1.46 \\
\hline 6 & Stappia indica & MF928372 & 2.25 & Unclassified & & 1.25 & Unclassified & & 2.57 & $\begin{array}{l}\text { Oceanicaulis } \\
\text { alexandrii }\end{array}$ & FN562402 & 0.55 & Alcanivorax sp. & KU681506 & 1.19 \\
\hline 7 & $\begin{array}{l}\text { Rhodococcus } \\
\text { fascians }\end{array}$ & MG205633 & 1.71 & Halomonas sp. & KY474018 & 0.33 & $\begin{array}{l}\text { Rhodobacteraceae } \\
\text { bacterium }\end{array}$ & KM279014 & 1.79 & Unclassified & & 0.39 & $\begin{array}{l}\text { Rhodobacteraceae } \\
\text { bacterium }\end{array}$ & KM279014 & 0.83 \\
\hline 8 & $\begin{array}{l}\text { Phyllobacteriaceae } \\
\text { bacterium }\end{array}$ & KM279012 & 1.47 & Ahrensia kielensis & KM613150 & 0.32 & Legionella sp. & KU508793 & $1.42 \frac{I}{b}$ & $\begin{array}{l}\text { Phyllobacteriaceae } \\
\text { bacterium }\end{array}$ & KM279012 & 0.33 & Legionella sp. & KU508793 & 0.81 \\
\hline 9 & $\begin{array}{l}\text { Pseudomonas } \\
\text { stutzeri }\end{array}$ & MF383463 & 1.29 & $\begin{array}{l}\text { Pseudoalteromonas } \\
\text { lipolytica }\end{array}$ & LC221845 & 0.32 & $\begin{array}{l}\text { Marinobacter } \\
\text { lipolyticus }\end{array}$ & KX818042 & $1.30 \mathrm{~s}$ & Stappia sp. & LT629784 & 0.24 & Marivita roseacus & NR_132662 & 0.65 \\
\hline 10 & Alteromonas sp. & MG010445 & 1.14 & Thalassospira sp. & LN868390 & 0.28 & Stappia indica & KY616246 & 1.20 & $\begin{array}{l}\text { Alteromonas } \\
\text { australica }\end{array}$ & КР099958 & 0.23 & Unclassified & & 0.54 \\
\hline 11 & Unclassified & & 1.13 & $\begin{array}{l}\text { Mesoflavibacter } \\
\text { zeaxanthinifaciens }\end{array}$ & NR_114033 & 0.26 & $\begin{array}{l}\text { Planctomyces } \\
\text { maris }\end{array}$ & NR_025327 & 0.99 & Arenibacter sp. & KU948154 & 0.22 & $\begin{array}{l}\text { Planctomyces } \\
\text { maris }\end{array}$ & NR_025327 & 0.49 \\
\hline 12 & $\begin{array}{l}\text { Marinobacter } \\
\text { alkaliphilus }\end{array}$ & MG029454 & 1.06 & Legionella sp. & KU508793 & 0.25 & $\begin{array}{l}\text { Alteromonas } \\
\text { macleodii }\end{array}$ & KY436447 & $0.90 \quad 1$ & Marivita roseacus & NR_132662 & 0.18 & Stappia indica & KY616246 & 0.40 \\
\hline 13 & $\begin{array}{l}\text { Pseudomonas } \\
\text { xinjiangensis }\end{array}$ & KU601273 & 1.04 & Unclassified & & 0.22 & $\begin{array}{l}\text { Marinobacter } \\
\text { adhaerens }\end{array}$ & KY604871 & $0.78 \quad 1$ & Methylophaga sp. & KC295343 & 0.15 & Unclassified & & 0.36 \\
\hline 14 & $\begin{array}{l}\text { Marinobacter } \\
\text { adhaerens }\end{array}$ & KY604871 & 0.76 & Vibrio harveyi & KY697683 & 0.22 & $\begin{array}{l}\text { Phyllobacteriaceae } \\
\text { bacterium }\end{array}$ & KM279012 & $0.70 \mathrm{~L}$ & Legionella sp. & KU508793 & 0.15 & Unclassified & & 0.25 \\
\hline 15 & Pseudomonas sp. & KX000012 & 0.48 & $\begin{array}{l}\text { Alteromonas } \\
\text { addita }\end{array}$ & KY787160 & 0.22 & Alcanivorax sp. & KU681506 & $\begin{array}{rr}0.47 \quad 1 \\
& a\end{array}$ & $\begin{array}{l}\text { Marinobacter } \\
\text { adhaerens }\end{array}$ & KY604871 & 0.15 & Thalassospira sp. & LN868390 & 0.24 \\
\hline 16 & $\begin{array}{l}\text { Oceanicaulis } \\
\text { alexandrii }\end{array}$ & FN562403 & 0.38 & Methylophaga sp. & KC295343 & 0.19 & Marinobacter sp. & LT221258 & $0.40 s$ & Stappia indica & KY616246 & 0.12 & $\begin{array}{l}\text { Oceanicola } \\
\text { nitratireducens }\end{array}$ & NR_116369 & 0.22 \\
\hline 17 & $\begin{array}{l}\text { Pseudoalteromonas } \\
\text { prydzensis }\end{array}$ & KX417143 & 0.29 & Hyphomonas sp. & KM2790018 & 0.17 & Marivita roseacus & NR_132662 & 0.37 & Thalassospira sp. & LN868390 & 0.10 & $\begin{array}{l}\text { Oceanicaulis } \\
\text { alexandrii }\end{array}$ & FN562403 & 0.19 \\
\hline 18 & Hoeflea sp. & КС469076 & 0.28 & Halomonas sp. & KX780067 & 0.15 & Unclassified & & 0.33 & & & & Marivita roseacus & NR_132662 & 0.17 \\
\hline 19 & Sphingomonas sp. & KX419227 & 0.25 & Stappia sp. & LT629784 & 0.10 & Stappia indica & KY616246 & 0.33 & & & & Marivita roseacus & NR_132662 & 0.17 \\
\hline 20 & Unclassified & & 0.23 & $\begin{array}{l}\text { Phyllobacteriaceae } \\
\text { bacterium }\end{array}$ & KM279375 & 0.12 & Hoeflea sp. & КС469076 & 0.32 & & & & Pseudomonas sp. & KY020318 & 0.16 \\
\hline
\end{tabular}


Table 4-1. Comparison of shared and specific OTUs on day 5.

\begin{tabular}{|c|c|c|c|c|c|c|c|}
\hline \multirow[b]{2}{*}{ Sample } & \multirow{2}{*}{$\begin{array}{l}\text { No. of } \\
\text { OTUs }\end{array}$} & \multicolumn{2}{|c|}{ Initial (day 0) } & \multicolumn{2}{|c|}{ Red (5R) } & \multicolumn{2}{|c|}{ Yellow (5Y) } \\
\hline & & $\begin{array}{c}\text { OTUs } \\
(\%)\end{array}$ & $\begin{array}{c}\text { Reads } \\
(\%)\end{array}$ & $\begin{array}{c}\text { OTUs } \\
(\%)\end{array}$ & $\begin{array}{c}\text { Reads } \\
(\%)\end{array}$ & $\begin{array}{c}\text { OTUs } \\
(\%)\end{array}$ & $\begin{array}{c}\text { Reads } \\
(\%)\end{array}$ \\
\hline I-R-Y & 26 & 26.26 & 86.10 & 27.66 & 62.57 & 26.53 & 76.57 \\
\hline $\mathrm{I}-\mathrm{R}$ & 10 & 10.10 & 1.50 & 10.64 & 1.20 & - & - \\
\hline $\mathrm{I}-\mathrm{Y}$ & 15 & 15.15 & 5.26 & - & - & 15.31 & 18.97 \\
\hline $\mathrm{R}-\mathrm{Y}$ & 18 & - & - & 19.15 & 1.25 & 18.37 & 2.26 \\
\hline I & 48 & 48.48 & 7.14 & - & - & - & - \\
\hline $\mathrm{R}$ & 40 & - & - & 42.55 & 34.98 & - & - \\
\hline $\mathrm{Y}$ & 39 & - & - & - & - & 39.80 & 2.20 \\
\hline Total & 196 & 100.00 & 100.00 & 100.00 & 100.00 & 100.00 & 100.00 \\
\hline
\end{tabular}

Table 4-2. Comparison of shared and specific OTUs on day 15.

\begin{tabular}{cccccc}
\hline \multirow{2}{*}{ Sample } & \multirow{2}{*}{ No. of } & \multicolumn{2}{c}{ Red15R } & \multicolumn{2}{c}{ Red15Y } \\
\cline { 3 - 6 } & OTUs & OTUs (\%) & Reads (\%) & OTUs (\%) & Reads (\%) \\
\hline R-Y & 37 & 47.44 & 97.31 & 38.54 & 91.20 \\
R & 41 & 52.56 & 2.69 & - & - \\
Y & 59 & - & - & 61.46 & 8.80 \\
Total & 137 & 100.00 & 100.00 & 100.00 & 100.00 \\
\hline
\end{tabular}

cultures were compared (Fig. 4). Photosynthesis occurred well in the red wavelength, and the microbial community was rapidly transformed so that the community structure was similar on day 5 . On the other hand, the yellow
Table 4-3. Comparison of the shared and specific OTUs of two separate samples grown under the red light.

\begin{tabular}{cccccc}
\hline \multirow{2}{*}{ Sample } & \multirow{2}{*}{ No. of } & \multicolumn{2}{c}{ Red1 } & \multicolumn{2}{c}{ Red2 } \\
\cline { 3 - 6 } & OTUs & OTUs (\%) & Reads (\%) & OTUs (\%) & Reads (\%) \\
\hline R1-R2 & 53 & 55.21 & 98.56 & 56.38 & 97.93 \\
R1 & 43 & 44.79 & 1.44 & - & - \\
R2 & 41 & - & - & 43.62 & 2.07 \\
Total & 137 & 100.00 & 100.00 & 100.00 & 100.00 \\
\hline
\end{tabular}

Table 4-4. Comparison of the shared and specific OTUs of two separate samples grown under the yellow light.

\begin{tabular}{|c|c|c|c|c|c|}
\hline \multirow{2}{*}{ Sample } & \multirow{2}{*}{$\begin{array}{l}\text { No. of } \\
\text { OTUs }\end{array}$} & \multicolumn{2}{|c|}{ Yellow 1} & \multicolumn{2}{|c|}{ Yellow 2} \\
\hline & & OTUs (\%) & Reads (\%) & OTU (\%) & Reads (\%) \\
\hline Y1-Y2 & 13 & 13.27 & 62.73 & 13.13 & 3.89 \\
\hline Y1 & 85 & 86.73 & 37.27 & - & - \\
\hline $\mathrm{Y} 2$ & 86 & - & - & 86.87 & 96.11 \\
\hline Total & 184 & 100.00 & 100.00 & 100.00 & 100.00 \\
\hline
\end{tabular}

wavelength had relatively slow photosynthesis, and the bacteria showed more influence on each other. The number of OTUs shared within the two cultures was small even under the same condition due to the randomly inoculated bacteria, as expected (Table 4-4 and Figs. 3C and 4).

As a result, the red wavelength has a positive effect on

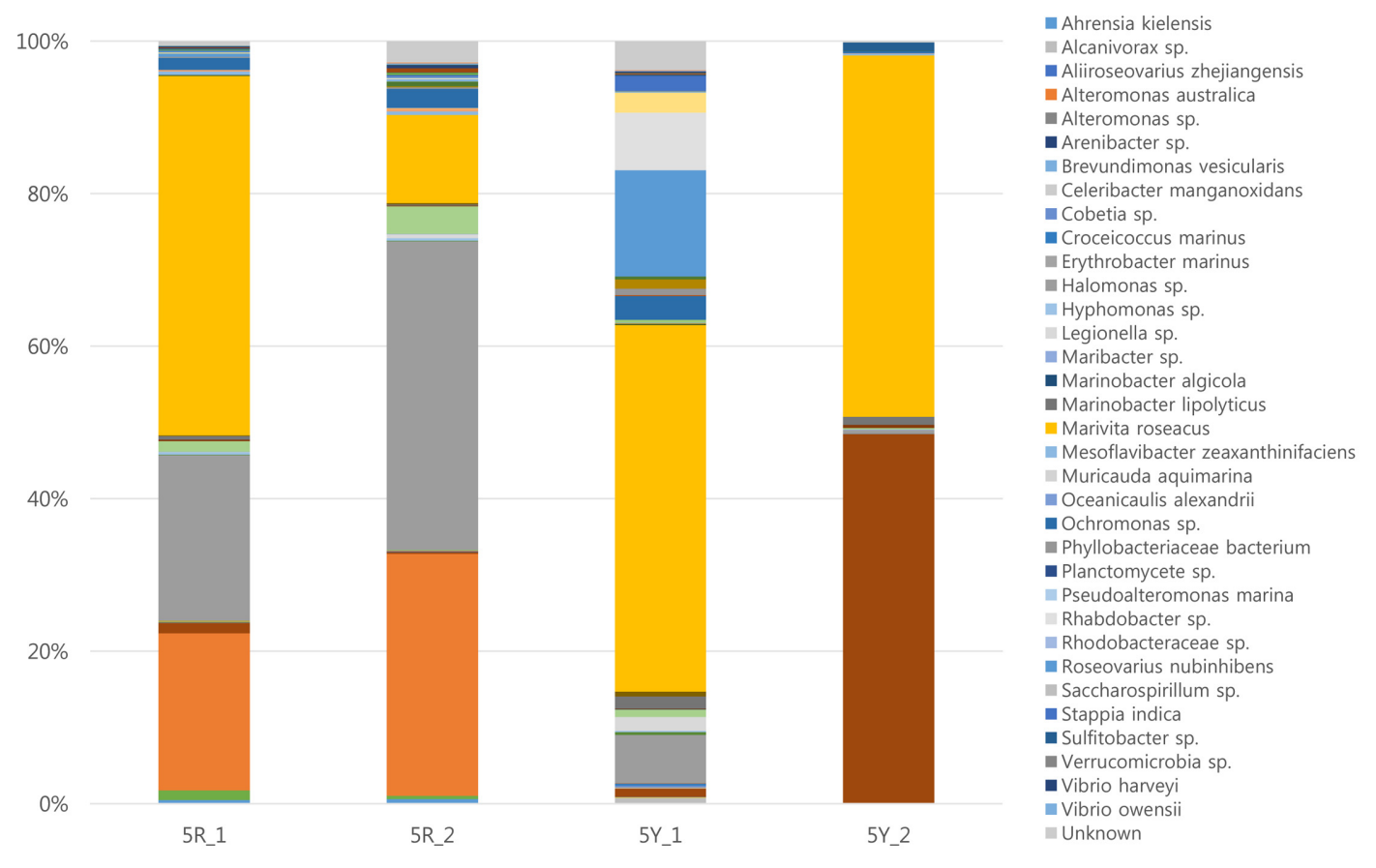

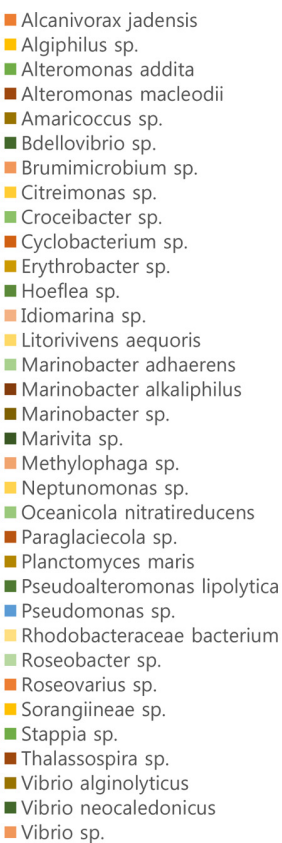

Algiphilus sp.

Alteromonas addita

Alteromonas macleodii

Bdellovibrio sp.

Brumimicrobium sp.

Eroceibacter sp.

- Cyclobacterium sp.

Erythrobacter sp.

Hoeflea sp.

Litorivivens aequoris

Marinobacter adhaerens

Marinobacter sp.

Neptunomonas

Oceanicola nitratireducens

- Paraglaciecola sp.

Pseudoalteromonas lipolytica

Pseudomonas sp.

Rhodobacteraceae bacterium

Vibrio neocaledonicus

- Vibrio sp.

Fig. 4. Bacterial community structures at the species level on day 5 of the red and yellow wavelengths. 
Table 5. Microbial species observed on day 15 samples under the red and yellow LED lights.

\begin{tabular}{|c|c|c|c|c|c|c|c|c|c|c|c|}
\hline \multicolumn{6}{|c|}{ Day 15 - Red } & \multicolumn{6}{|c|}{ Day 15 - Yellow } \\
\hline Species & $\begin{array}{c}\text { Contigs } \\
(\%)\end{array}$ & Phylum & Class & Order & Family & Species & $\begin{array}{c}\text { Contigs } \\
(\%)\end{array}$ & Phylum & Class & Order & Family \\
\hline Marivita roseacus & 88.64 & Proteobacteria & Alphaproteobacteria & Rhodobacterales & Rhodobacteraceae & Marivita roseacus & 88.12 & Proteobacteria & Alphaproteobacteria & Rhodobacterales & Rhodobacteraceae \\
\hline Halomonas sp. & 4.92 & Proteobacteria & Gammaproteobacteria & Oceanospirillales & Halomonadaceae & Rhabdobacter sp. & 4.2 & Bacteroidetes & Cytophagia & Cytophagales & Cytophagaceae \\
\hline $\begin{array}{l}\text { Rhabdobacter } \\
\text { sp. }\end{array}$ & 2.09 & Bacteroidetes & Cytophagia & Cytophagales & Cytophagaceae & Legionella sp. & 2.16 & Proteobacteria & Gammaproteobacteria & Legionellales & Legionellaceae \\
\hline $\begin{array}{l}\text { Oceanicaulis } \\
\text { alexandrii }\end{array}$ & 1.28 & Proteobacteria & Alphaproteobacteria & Caulobacterales & Hypomonadaceae & $\begin{array}{l}\text { Planctomyces } \\
\text { maris }\end{array}$ & 1.29 & Proteobacteria & Planctomycetia & Planctomycetales & Planctomycetaceae \\
\hline $\begin{array}{l}\text { Phyllobacteriaceae } \\
\text { bacterium }\end{array}$ & 0.77 & Proteobacteria & Alphaproteobacteria & Rhizobiales & Phyllobacteriaceae & Thalassospira sp. & 0.63 & Proteobacteria & Alphaproteobacteria & Rhodospirillales & Rhodospirillaceae \\
\hline Methylophaga sp. & 0.36 & Proteobacteria & Gammaproteobacteria & Thiotrichales & Piscirickettsiaceae & $\begin{array}{l}\text { Oceanicaulis } \\
\text { alexandrii }\end{array}$ & 0.5 & Proteobacteria & Alphaproteobacteria & Caulobacterales & Hypomonadaceae \\
\hline Legionella sp. & 0.35 & Proteobacteria & Gammaproteobacteria & Legionellales & Legionellaceae & Planctomycete sp. & 0.39 & Planctomycetes & Planctomycetacia & Planctomycetales & Planctomycetaceae \\
\hline $\begin{array}{l}\text { Marinobacter } \\
\text { adhaerens }\end{array}$ & 0.35 & Proteobacteria & Gammaproteobacteria & Alteromanadales & Alteromonadaceae & Halomonas sp. & 0.33 & Proteobacteria & Gammaproteobacteria & Oceanospirillales & Halomonadaceae \\
\hline Thalassospira sp. & 0.25 & Proteobacteria & Alphaproteobacteria & Rhodospirillales & Rhodospirillaceae & $\begin{array}{l}\text { Phyllobacteriaceae } \\
\text { bacterium }\end{array}$ & 0.3 & Proteobacteria & Alphaproteobacteria & Rhizobiales & Phyllobacteriaceae \\
\hline $\begin{array}{l}\text { Planctomyces } \\
\text { maris }\end{array}$ & 0.23 & Proteobacteria & Planctomycetacia & Planctomycetales & Planctomycetaceae & Methylophaga sp. & 0.3 & Proteobacteria & Gammaproteobacteria & Thiotrichales & Piscirickettsiaceae \\
\hline Hyphomonas sp. & 0.11 & Proteobacteria & Alphaproteobacteria & Caulobacterales & Hyphomonadaceae & $\begin{array}{l}\text { Pseudoalteromonas } \\
\text { lipolytica }\end{array}$ & 0.28 & Proteobacteria & Gammaproteobacteria & Alteromonadales & Pseudanabaenaceae \\
\hline $\begin{array}{l}\text { Pseudoalteromonas } \\
\text { lipolytica }\end{array}$ & 0.11 & Proteobacteria & Gammaproteobacteria & Alteromanadales & Psedonabaenaceae & $\begin{array}{l}\text { Brumimicrobium } \\
\text { sp. }\end{array}$ & 0.26 & Bacteroidetes & Flavobacteriia & Flavobacteriales & Cryomorphaceae \\
\hline $\begin{array}{l}\text { Rhodobacteraceae } \\
\text { bacterium }\end{array}$ & 0.08 & Proteobacteria & Alphaproteobacteria & Rhodobacterales & Rhodobacteraceae & Sorangiineae sp. & 0.25 & Proteobacteria & Deltaproteobacteria & Myxococcales & $\begin{array}{l}\text { Polyangiaceae } \\
\text { (Labilithrix) }\end{array}$ \\
\hline $\begin{array}{l}\text { Brumimicrobium } \\
\text { sp. }\end{array}$ & 0.07 & Bacteroidetes & Flavobacteriia & Flavobacteriales & Cryomorphaceae & $\begin{array}{l}\text { Rhodobacteraceae } \\
\text { bacterium }\end{array}$ & 0.24 & Proteobacteria & Alphaproteobacteria & Rhodobacterales & Rhodobacteraceae \\
\hline $\begin{array}{l}\text { Marinobacter } \\
\text { lipolyticus }\end{array}$ & 0.07 & Proteobacteria & Gammaproteobacteria & Alteromanadales & Alteromonadaceae & $\begin{array}{l}\text { Marinobacter } \\
\text { lipolyticus }\end{array}$ & 0.23 & Proteobacteria & Gammaproteobacteria & Alteromonadales & Alteromonadaceae \\
\hline $\begin{array}{l}\text { Alcanivorax } \\
\text { jadensis }\end{array}$ & 0.06 & Proteobacteria & Gammaproteobacteria & Oceanospirillales & Alcanivoracaceae & Hoeflea sp. & 0.11 & Proteobacteria & Alphaproteobacteria & Rhizobiales & Phyllobacteriaceae \\
\hline $\begin{array}{l}\text { Roseovarius } \\
\text { nubinhibens }\end{array}$ & 0.06 & Proteobacteria & Alphaproteobacteria & Rhodobacterales & Rhodobacteraceae & Marivita sp. & 0.1 & Proteobacteria & Alphaproteobacteria & Rhodobacterales & Rhodobacteraceae \\
\hline Hoeflea sp. & 0.06 & Proteobacteria & Alphaproteobacteria & Rhizobiales & Phyllobacteriaceae & $\begin{array}{l}\text { Marinobacter } \\
\text { adhaerens }\end{array}$ & 0.07 & Proteobacteria & Gammaproteobacteria & Alteromonadales & Alteromonadaceae \\
\hline $\begin{array}{l}\text { Litorivivens } \\
\text { aequoris }\end{array}$ & 0.06 & Proteobacteria & Gammaproteobacteria & Unclassified & Unclassified & $\begin{array}{l}\text { Alcanivorax } \\
\text { jadensis }\end{array}$ & 0.06 & Proteobacteria & Gammaproteobacteria & Oceanospirillales & Alcanivoracaceae \\
\hline Sorangiineae sp. & 0.03 & Proteobacteria & Deltaproteobacteria & Myxococcales & $\begin{array}{l}\text { Polyangiaceae } \\
\text { (Labilithrix) }\end{array}$ & Hyphomonas sp. & 0.06 & Proteobacteria & Alphaproteobacteria & Caulobacterales & Hyphomonadaceae \\
\hline Marivita sp. & 0.02 & Proteobacteria & Alphaproteobacteria & Rhodobacterales & Rhodobacteraceae & $\begin{array}{l}\text { Litorivivens } \\
\text { aequoris }\end{array}$ & 0.05 & Proteobacteria & Gammaproteobacteria & Unclassified & Unclassified \\
\hline Planctomycete sp. & 0.02 & Planctomycetes & Planctomycetacia & Planctomycetales & Planctomycetaceae & $\begin{array}{l}\text { Roseovarius } \\
\text { nubinhibens }\end{array}$ & 0.03 & Proteobacteria & Alphaproteobacteria & Rhodobacterales & Rhodobacteraceae \\
\hline Sulfitobacter sp. & 0.02 & Proteobacteria & Alphaproteobacteria & Rhodobacterales & Rhodobacteraceae & Sulfitobacter sp. & 0.03 & Proteobacteria & Alphaproteobacteria & Rhodobacterales & Rhodobacteraceae \\
\hline
\end{tabular}


the growth of T. suecica. However, its growth was also affected by the randomly established initial bacterial community structure, which may be related to the difference in the metabolites the bacteria release. As photosynthetic microalgae growth increases in 5-10 days after inoculation, consuming the carbon dioxide produced by the heterotrophic bacteria, the initial microbial community continues to change, optimizing themselves in the oxygen-rich environment. In fact, aerobic bacteria can promote microalgal growth by reducing the photosynthetic oxygen in nature [32]. We could therefore expect that the remaining species would be aerobic heterotrophic or photosynthetic bacteria (Table 5). On day 15, all remaining species in the red and yellow lights were aerobic bacteria due to oxygen produced by the photosynthesis of T. suecica. Especially, M. roseacus seems to be the most dominant because it is aerobic and can photosynthesize. This study can be taken further by adding organic matter or specific bacteria and more algae. Actually, earlier studies proposed that amino acids and vitamins regulate the relationship between microalgae and bacteria $[33,34]$. When cultured in medium with extra additives, beneficial effects were enhanced extending our knowledge of interaction between the microalgae and its associated bacteria [12].

In conclusion, we herein introduced the NGS technique to analyze the precise microbial community structure changes during the culture of $T$. suecica, which has been difficult and complicated to accomplish by conventional methods. As a result, we were able to extend our knowledge about the interaction between microalgae and heterotrophic bacteria in a complicated aquatic microbial ecosystem. Algae-bacteria consortia can be seen as a very important concept in understanding the aquatic environment and ecosystem, and may also provide important knowledge for biotechnological applications including in wastewater treatment, bioremediation, and sustainable aquaculture [35].

\section{Acknowledgment}

This study was supported by a grant from the National Institute of Fisheries Science (R2019021).

\section{Conflict of Interest}

The authors have no financial conflicts of interest to declare.

\section{References}

1. Muller-Feuga A, Robert R, Cahu C, Robin J, Divanach P. 2003. Uses of microalgae in aquaculture. Live Feeds Marine Aquac. 253-299.

2. Austin B, Day JG. 1990. Inhibition of prawn pathogenic Vibrio spp. by a commercial spray-dried preparation of Tetraselmis suecica. Aquaculture 90: 389-392.

3. Austin B, Baudet E, Stobie M. 1992. Inhibition of bacterial fish pathogens by Tetraselmis suecica. J. Fish Dis. 15: 55-61.

4. Irianto A, Austin B. 2002. Probiotics in aquaculture. J. Fish Dis. 25: 633-642.

5. Carballo-Cárdenas EC, Tuan PM, Janssen M, Wijffels RH. 2003. Vitamin E ( $\alpha$-tocopherol) production by the marine microalgae Dunaliella tertiolecta and Tetraselmis suecica in batch cultivation. Biomol. Eng. 20: 139-147.

6. Han MA, Hong SJ, Kim ZH, Cho BK, Lee H, Choi HK, et al. 2018. Enhanced production of fatty acids via redirection of carbon flux in marine microalga Tetraselmis sp. J. Microbiol. Biotechnol. 28: 267-274.

7. Lee SJ, Choi WS, Park GH, Kim TH, Oh C, Heo SJ, et al. 2018. Flocculation Effect of Alkaline Electrolyzed Water (AEW) on Harvesting of Marine Microalga Tetraselmis sp. J. Microbiol. Biotechnol. 28: 432-438.

8. Materassi R, Tredici M, Milicia F, Sili C, Pelosi E, Vincenzini M, et al. 1983. Development of a production size system for the mass culture of marine microalgae. Energy from Biomass. pp. 150-158. Reidel Publishing Company, Boston.

9. Fabregas J, Herrero C, Cabezas B, Abalde J. 1985. Mass culture and biochemical variability of the marine microalga Tetraselmis suecica Kylin (Butch) with high nutrient concentrations. Aquaculture 49: 231-244.

10. Abiusi F, Sampietro G, Marturano G, Biondi N, Rodolfi L, D'Ottavio M, et al. 2014. Growth, photosynthetic efficiency, and biochemical composition of Tetraselmis suecica F\&MM33 grown with LEDs of different colors. Biotechnol. Bioeng. 111: $956-964$.

11. Zhao Y, Wang J, Zhang H, Yan C, Zhang Y. 2013. Effects of various LED light wavelengths and intensities on microalgaebased simultaneous biogas upgrading and digestate nutrient reduction process. Bioresour. Technol. 136: 461-468.

12. Han J, Zhang L, Wang S, Yang G, Zhao L, Pan K. 2016. Coculturing bacteria and microalgae in organic carbon containing medium. J. Biol. Res.-Thessaloniki. 23: 8.

13. Ramanan R, Kim BH, Cho DH, Oh HM, Kim HS. 2016. Algae-bacteria interactions: evolution, ecology and emerging applications. Biotechnol. Adv. 34: 14-29.

14. Biondi N, Cheloni G, Tatti E, Decorosi F, Rodolfi L, Giovannetti L, et al. 2017. The bacterial community associated with Tetraselmis suecica outdoor mass cultures. J. Appl. Phycol. 29: 67-78. 
15. Fierer N, Jackson JA, Vilgalys R, Jackson RB. 2005. Assessment of soil microbial community structure by use of taxon-specific quantitative PCR assays. Appl. Environ. Microbiol. 71: 4117-4120.

16. Zhao $Y$, Duan $C$, Zhang $X$, Chen $H$, Ren $H$, Yin $Y$, Ye L. 2018. Insights into the gut microbiota of freshwater shrimp and its associations with the surrounding microbiota and environmental factors. J. Microbiol. Biotechnol. 28: 946-956.

17. Chen Y, Ye L, Zhao F, Xiao L, Cheng S, Zhang XX. 2017. Bacterial community shift during the startup of a full-scale oxidation ditch treating sewage. J. Microbiol. Biotechnol. 27: 141-148.

18. Kozich JJ, Westcott SL, Baxter NT, Highlander SK, Schloss PD. 2013. Development of a dual-index sequencing strategy and curation pipeline for analyzing amplicon sequence data on the MiSeq Illumina sequencing platform. Appl. Environ. Microbiol. 79: 5112-5120.

19. Kim TH, Lee Y, Han SH, Hwang SJ. 2013. The effects of wavelength and wavelength mixing ratios on microalgae growth and nitrogen, phosphorus removal using Scenedesmus sp. for wastewater treatment. Bioresour. Technol. 130: 75-80.

20. Oh SJ, Kwon HK, Jeon JY, Yang HS. 2015. Effect of monochromatic light emitting diode on the growth of four microalgae species (Chlorella vulgaris, Nitzschia sp., Phaeodactylum tricornutum, Skeletonema sp.). J. Kor. Soc. Mar. Env. Saf. 21: 1-8.

21. Medler S, Mykles DL. 2003. Analysis of myofibrillar proteins and transcripts in adult skeletal muscles of the American lobster Homarus americanus: variable expression of myosins, actin and troponins in fast, slow-twitch and slowtonic fibres. J. Exp. Biol. 206: 3557-3567.

22. Yu X, Mykles DL. 2003. Cloning of a muscle-specific calpain from the American lobster Homarus americanus: expression associated with muscle atrophy and restoration during moulting. J. Exp. Biol. 206: 561-575.

23. Schloss PD, Westcott SL, Ryabin T, Hall JR, Hartmann M, Hollister EB, et al. 2009. Introducing mothur: open-source, platform-independent, community-supported software for describing and comparing microbial communities. Appl. Environ. Microbiol. 75: 7537-7541.

24. Staley C, Unno T, Gould T, Jarvis B, Phillips J, Cotner J, et al. 2013. Application of Illumina next-generation sequencing to characterize the bacterial community of the Upper Mississippi River. J. Appl. Microbiol. 115: 1147-1158.
25. Thijs S, Op De Beeck M, Beckers B, Truyens S, Stevens V, Van Hamme JD, et al. 2017. Comparative evaluation of four bacteria-specific primer pairs for $16 \mathrm{~S}$ rRNA gene surveys. Front Microbiol. 8: 494.

26. Klindworth A, Pruesse E, Schweer T, Peplies J, Quast C, Horn M, et al. 2013. Evaluation of general 16S ribosomal RNA gene PCR primers for classical and next-generation sequencing-based diversity studies. Nucleic Acids Res. 41: e1. doi: $10.1093 /$ nar/gks808

27. Ugwu C, Aoyagi H, Uchiyama H. 2007. Influence of irradiance, dissolved oxygen concentration, and temperature on the growth of Chlorella sorokiniana. Photosynthetica. 45: 309-311.

28. Makridis P, Ferreira T, Kokou F, Tsigenopoulos CS, Divanach P. 2012. Quantitative and qualitative aspects of bacterial communities associated with cultures of Chlorella minutissima. J. World Aquacul. Soc. 43: 571-578.

29. Lee JK, Lim JH, Lee TY. 2012. Cultivation of Tetraselmis suecica under different types of light emitting diodes. Int. J. Environ. 21: 757-761.

30. Green DH, Echavarri-Bravo V, Brennan D, Hart MC. 2015. Bacterial diversity associated with the coccolithophorid algae Emiliania huxleyi and Coccolithus pelagicus f. braarudii. Biomed. Res. Int. 2015: 194540.

31. Budinoff CR, Dunlap JR, Hadden M, Buchan A. 2011. Marivita roseacus sp. nov., of the family Rhodobacteraceae, isolated from a temperate estuary and an emended description of the genus Marivita. J. Gen. Appl. Microbiol. 57: 259-267.

32. Mouget JL, Dakhama A, Lavoie MC, de la Noüe J. 1995. Algal growth enhancement by bacteria: Is consumption of photosynthetic oxygen involved? FEMS Microbiol. Ecol. 18: 35-43.

33. Ohwada K. 1973. Seasonal cycles of vitamin B12, thiamine and biotin in Lake Sagami. Patterns of their distribution and ecological significance. Int. Rev. Hydrobiol. 58: 851-871.

34. Ohwada K, Taga N. 1972. Distribution and seasonal variation of vitamin B12, thiamine and biotin in the sea. Mar. Chem. 1: 61-73.

35. Fuentes JL, Garbayo I, Cuaresma M, Montero Z, Gonzálezdel-Valle M, Vílchez C. 2016. Impact of microalgae-bacteria interactions on the production of algal biomass and associated compounds. Mar. Drugs. 14(5). pii: E100. 